Sains Malaysiana 48(1)(2019): 7-13

http://dx.doi.org/10.17576/jsm-2019-4801-02

\title{
Effects of Lignosulfonates on Callus Proliferation and Shoot Induction of Recalcitrant Indica Rice
}

(Kesan Lignosulfonat ke atas Proliferasi Kalus dan Induksi Tunas Beras Indica Rekalsitran)

\author{
LeE-Yoon Low, Janna Ong ABdUllah, ChIEN-YeOng WeE, RogaYAH SEKELI, \\ CHUN-KEAT TAN, JIUN-YAN LOH \& KOK-SONG LAI*
}

\begin{abstract}
In vitro culture of recalcitrant indica rice cultivar through intervening callus is difficult due to long regeneration period. Therefore, this study was undertaken to evaluate the growth promoting effects of lignosulfonate (LS) on callus proliferation and shoot induction of Malaysian recalcitrant indica rice cv. MR219. LS is a by-product of wood industry, commonly used as a plant growth enhancer. Seed derived calli were proliferated on Murashige and Skoog (MS) medium supplemented with different ion-chelated LS (calcium LS: CaLS and sodium LS: NaLS) at 50, 100, 150, and $200 \mathrm{mg} / \mathrm{L}$. MS supplemented with $100 \mathrm{mg} / \mathrm{L}$ CaLS significantly increased the callus proliferation rate and adventitious root formation. In shoot induction study, both LSs did not enhance the shoot induction efficiency as compared to the control. However, the formation of albino shoot increased in MS fortified with $100 \mathrm{mg} / \mathrm{L}$ CaLS. Further chlorophyll and molecular analyses showed that, albino shoots induced from $100 \mathrm{mg} / \mathrm{L}$ CaLS had severe reduction in total chlorophyll content and expression of both chlorophyll-associated genes, chlorophyll a/b-binding protein 1 (OsCAB1R) and young seedling albino (OsYSA). Taken together, LS improves callus proliferation rate and modulate different physiological responses during plant growth of recalcitrant indica rice.
\end{abstract}

Keywords: Albino; callus proliferation; indica cv. MR219; lignosulfonate; regeneration

ABSTRAK

Pengkulturan kultivar beras indica rekalsitran secara in vitro melalui kalus intervensi adalah sukar kerana tempoh regenerasinya yang panjang. Oleh itu, kajian ini dijalankan untuk menilai kesan lignosulfonat (LS) terhadap proliferasi kalus dan induksi tunas beras indica rekalsitran Malaysia cv. MR219. LS adalah produk sampingan daripada industri kayu yang biasanya digunakan sebagai perangsang pertumbuhan tumbuhan dalam baja. Kalus diperoleh daripada biji diproliferasi atas medium Murashige dan Skoog (MS) yang ditambah dengan pengikat ion LS (kalsium LS: CaLS dan natrium LS: NaLS) pada kepekatan 50, 100, 150 dan $200 \mathrm{mg} / \mathrm{L}$. MS yang ditambah dengan $100 \mathrm{mg} / \mathrm{L}$ CaLS didapati meningkatkan kadar perkembangan kalus dan pembentukan akar serabut. Dalam kajian induksi tunas, kedua-dua LSs tidak meningkatkan kecekapan induksi berbanding dengan kawalan. Walau bagaimanapun, penghasilan albino meningkat pada MS yang ditambah dengan $100 \mathrm{mg} / \mathrm{L}$ CaLS. Analisis klorofil dan molekul menunjukkan bahawa albino yang diinduksi daripada $100 \mathrm{mg} / \mathrm{L}$ CaLS mempunyai pengurangan yang banyak dalam jumlah kandungan klorofil dan pengekspresan kedua-dua gen yang berkaitan dengan klorofil, chlorophyll a/b-binding protein 1 (OsCABIR) dan young seedling albino (OsYSA). Sebagai kesimpulan, LS meningkatkan kadar proliferasi kalus dan memodulasi tindak balas fisiologi yang berlainan semasa pertumbuhan beras indica rekalsitran.

Kata kunci: Albino; indica cv. MR219; lignosulfonat; proliferasi kalus; regenerasi

\section{INTRODUCTION}

Rice is one of the major staple foods in the world. In 2016, the rice production of Malaysia was recorded at 3 million tons (FAO 2017). However, the current rice production is not sufficient to sustain the local domestic consumption requirements where Malaysia is still largely dependent on imported rice. Thus, to fulfill the local rice demand, research in rice has been generally focusing on improving the grain yield and quality. The Oryza sativa indica cv. MR219 is an important local rice cultivar with high yield and largely cultivated in Malaysia (FFTC 2002).
To date, major achievement in genetic manipulation of rice has been obtained mostly in japonica rice because of its better response to in vitro culture as compare to other cultivars (Andrew Kok et al. 2018; Visarada \& Sarma 2004). Nevertheless, crop improvement based on genetic manipulation on indica rice remains the major limiting factor due to its recalcitrant characteristics which include low regeneration rate, low transformation efficiency and as well as long regeneration period (Lai et al. 2011; MartinezTrujillo et al.2003; Mishra \& Rao 2016; Raghavendra et al. 2010; Sah et al. 2014; Sahoo et al. 2011). Low regeneration 
rate had been observed in previous studies whereby the regeneration efficiency was around $7 \%$ (Abiri et al. 2017) and $13 \%$ in MR219 (Htwe et al. 2011). Long embryogenic callus formation period was also observed in MR219 whereby 8 weeks was required for embryogenic callus formation prior to shoot regeneration (Zuraida et al. 2012). Hence, effective culture mediums for callus proliferation and shoot induction are prerequisite to ensure the success of genetic manipulation for traits improvement in recalcitrant indica rice.

Lignosulfonate (LS) is a sulfonated polymer arising from three phenylpropanoid monomers mainly, coniferyl, sinapyl and p-coumaryl alcohol. This complex polymer is a low-cost waste product from sulfite pulping process in wood industries that is already being commercialized as binding agent and dispersal for several industrial purposes (Almas et al. 2014; Yang et al. 2007). Commercial LS usually comes in different cation-chelated such as $\mathrm{Ca}$, $\mathrm{Na}, \mathrm{Zn}, \mathrm{K}$ or Fe, depending on the type of sulfite used in pulping process. In agriculture, the ability to chelate different micronutrient ions had made LS one of the ideal compositions in plant fertilizer, besides being costeffective as compared to other additives (Carrasco et al. 2012). It has also drawn considerable interest to be used as stimulant in plant growth and fructification (Ertani et al. 2011; Rodríguez-Lucena et al. 2009; Telysheva et al. 1997, 1992; van der Krieken et al. 2004). Additionally, LS also significantly enhances the rooting and shoot growth of ornamental plants (Telysheva et al. 1997, 1992).

Therefore, the present study was undertaken to extend in vitro application of LS in enhancing callus proliferation and shoot induction of recalcitrant Malaysian indica rice cv. MR219. Ultimately, we hope to improve the cultivation medium of this local recalcitrant indica rice through the supplementation of LS.

\section{MATERIALS AND METHODS}

\section{PLANT MATERIALS}

The recalcitrant Malaysian rice (Oryza sativa L. ssp. indica $\mathrm{cv}$. MR219) seeds used in this study were obtained from Malaysian Agricultural Research and Development Institute (MARDI), Seberang Prai, Penang.

\section{CHEMICALS}

Four different types of LS chosen were: industrial grade calcium lignosulfonate (iCaLS) and sodium lignosulfonate (iNaLS) from Borregaard, Norway; analytical grade calcium lignosulfonate (aCaLS) and sodium lignosulfonate (aNaLS) from Sigma, USA.

\section{SEEDS STERILIZATION}

The mature seeds were sterilized according to previously described protocol (Lim \& Lai 2017) with slight modifications. Briefly, seeds were dehusked and rinsed with sterile distilled water. Then, the seeds were surfacesterilized with $70 \%(\mathrm{v} / \mathrm{v})$ ethanol for $1 \mathrm{~min}$ and $50 \%(\mathrm{v} / \mathrm{v})$ Clorox for $30 \mathrm{~min}$, followed by washing 4-5 times with sterile distilled water. Sterile seeds were dried before use.

\section{CALLUS INDUCTION AND PROLIFERATION}

Gamborg's B5 basal medium (Gamborg et al. 1968) supplemented with $10 \mathrm{~g} / \mathrm{L}$ maltose, $10 \mathrm{mg} / \mathrm{L}$ NAA and 1 $\mathrm{mg} / \mathrm{L} 2,4-\mathrm{D}$ was employed to induce calli from sterile mature seeds in darkness for two weeks at $25 \pm 2{ }^{\circ} \mathrm{C}$. For callus proliferation study, $50 \mathrm{mg}$ of 2 -week old callus clump was cultured on Murashige and Skoog (MS) medium (Murashige \& Skoog 1962) containing 2 mg/L 2,4-D and $0.5 \mathrm{mg} / \mathrm{L}$ kinetin with different types and concentrations $(50,100,150$, and $200 \mathrm{mg} / \mathrm{L})$ of LS. LS was excluded in control treatment. Each petri dish contained nine callus clumps. The fresh weight (FW) and dry weight (DW) of the calli were measured after three weeks of cell proliferation. The FW of calli were measured directly before subjecting the calli for drying in oven at $70^{\circ} \mathrm{C}$. DW of the callus measurement were taken weekly until constant DW is obtained. Number of calli forming adventitious root in the control and optimum LS condition was also recorded. Experiments were performed in triplicates with three petri dishes per replicate.

\section{SHOOT INDUCTION}

MS medium containing $30 \mathrm{~g} / \mathrm{L}$ sucrose and $3 \mathrm{mg} / \mathrm{L}$ kinetin supplemented with different types and concentrations $(100,200,300,400$, and $500 \mathrm{mg} / \mathrm{L})$ of LS were used in shoot induction study. Meanwhile, control treatment had no LS. One-month old proliferated callus clumps were cultured in shoot induction medium under a photoperiod for $16 \mathrm{~h} \mathrm{light}$ and $8 \mathrm{~h}$ dark at $25 \pm 2{ }^{\circ} \mathrm{C}$. Number of shoots induced and the morphology changes were recorded after two months of in vitro cultivation. Experiments were performed in triplicates with 10 callus clumps per replicate.

\section{DETERMINATION OF TOTAL CHLOROPHYLL CONTENT}

To further confirm and measure the level of chlorophyll in induced albino shoot, chlorophyll content determination was performed according to protocol described by Yap and Lai (2017) with slight modifications. Fresh leaves (200 $\mathrm{mg}$ ) from the in vitro culture were ground in liquid nitrogen and homogenized in $5 \mathrm{~mL}$ of $80 \%(\mathrm{v} / \mathrm{v})$ acetone followed by centrifugation at $3000 \times \mathrm{g}$ for 20 min. The pigment content was analyzed with UV/Vis spectrophotometer at the wavelengths of 663 and 645 $\mathrm{nm}$. The total chlorophyll, chlorophylls a and b in each sample were determined using the Arnon's equation (1949): Chlorophyll a $(\mu \mathrm{g} / \mathrm{mL})=12.7\left(\mathrm{~A}_{663}\right)-2.69\left(\mathrm{~A}_{645}\right)$; Chlorophyll b $(\mu \mathrm{g} / \mathrm{mL})=22.9\left(\mathrm{~A}_{645}\right)-4.68\left(\mathrm{~A}_{663}\right)$ and total chlorophyll $(\mu \mathrm{g} / \mathrm{mL})=20.2\left(\mathrm{~A}_{645}\right)+8.02\left(\mathrm{~A}_{663}\right)$. 


\section{TOTAL RNA ISOLATION}

The total RNA of wild type (control) and albino shoot induced from $100 \mathrm{mg} / \mathrm{L}$ aCaLS medium was isolated using the RNeasy Mini Kit (Qiagen). Quality and purity of total RNA were measured using the Thermo Scientific ${ }^{\mathrm{TM}}$ NanoDrop 2000. The absorbance 260/280 nm of RNA was 1.8-2.0. Then, $1 \mathrm{ug}$ of total RNA was employed for first strand cDNA synthesized using QuantiNova reverse transcription kit (Qiagen).

\section{REAL-TIME REVERSE TRANSCRIPTION POLYMERASE CHAIN REACTION (QRT-PCR) ANALYSIS}

The chlorophyll-associated gene specific primers used were: forward 5' AGA TGG GTT TAG TGC GAC GAG 3' and reverse 5' TTT GGG ATC GAG GGA GTA TTT 3' for $O s C A B 1 R$; forward 5' CAG GAG ATT GCC GAT GGG TT 3' and reverse 5' TCG ATT CCC CGT GCA TAA GG 3' for OsYSA. The internal controls used for expression normalization were rice ubiquitin 5 (OsUBQ5) and elongation factor 1 alpha $(O s E F 1 \alpha)$ genes. The primers for these genes were: forward 5' TAG GCG TAG GCT CCT GTT CT 3' and reverse 5' ACA GAG GTG ATG CTA AGG TGT 3' for OsUBQ5; forward 5' ACC AGA TCA ACG AGC CCA AG 3' and reverse 5' CTC CAG TCT CAA CAC GAC CC 3' for OsEF $1 \alpha$. Real-time PCR analysis was conducted according to previously described protocol with slight modifications (Lai \& Takehisa 2013; Lai et al. 2012). Briefly, the analysis was performed using the Bio-Rad CFX96 system with SsoFast ${ }^{\mathrm{TM}}$ EvaGreen ${ }^{\circledR}$ Supermix (Bio-Rad). The qPCR profile was: Enzyme activation at $95^{\circ} \mathrm{C}$ for $30 \mathrm{~s}$ followed by 40 cycles of $95^{\circ} \mathrm{C}$ for $5 \mathrm{~s}$ and $60^{\circ} \mathrm{C}$ for $5 \mathrm{~s}$. Three technical replicates with three biological replicates each were performed for each sample. Efficiency-corrected $\Delta \mathrm{C}_{\mathrm{T}}$ and $\Delta \Delta \mathrm{C}_{\mathrm{T}}$ were used to calculate the relative differences in transcript expression according to Livak's method (Livak \& Schmittgen 2001).

\section{STATISTICAL ANALYSIS}

All data presented were the average \pm standard deviation (SD) of three biological replicates. The analysis of variance (ANOVA) was used in evaluating the level of significant differences at $p<0.05$ between the different conditions using the SPSS v.20 software (IBM Corp., Armonk, USA).

\section{RESULTS}

After three weeks of callus proliferation on medium supplemented with different types and concentrations of LS, callus FW and DW increments were observed in all the treatments except for iNaLS. The optimum callus proliferation rate was recorded at $100 \mathrm{mg} / \mathrm{L}$ aCaLS with $88 \% \mathrm{FW}$ (Figure 1(D)) and 32\% DW increments as compared to the control (Figure 1(E)). In addition, adventitious root formation was also enhanced (1.4-fold) in treatment supplemented with $100 \mathrm{mg} / \mathrm{L}$ aCaLS (Figure $1(\mathrm{~F})$ ). Calli produced in all the LS treatment appeared to be yellowish resembling the embryogenic cell except in $200 \mathrm{mg} / \mathrm{L}$ iNaLS treatment, whereby browning of callus was observed (Figure 1(A)). The $100 \mathrm{mg} / \mathrm{L} \mathrm{aCaLS}$ treated callus (Figure 1(C)) appeared to produce more adventitious roots in comparison to the control callus (Figure 1(B)). Moreover, both industrial and analytical grades of LS did not show significant different in their growth promoting effects

Based on the results in Figure 2(E) and 2(F), successful shoot induction was only observed in MS medium supplemented with either $100 \mathrm{mg} / \mathrm{L} \mathrm{aCaLS}$ or $200 \mathrm{mg} / \mathrm{L}$ aNaLS. However, half of the shoots induced from $100 \mathrm{mg} / \mathrm{L}$ aCaLS were found to be albino (Figure 2(D)) while none was observed in $200 \mathrm{mg} / \mathrm{L}$ of aNaLS. The wild type-liked shoots induced in $100 \mathrm{mg} / \mathrm{L}$ aCaLS were similar to the control (Figure 2(C)). In general, shoot induction efficiency was recorded lower in LS conditions as compared to the control. Besides, white microcalli were also observed in both LS and control cultures. Nevertheless, only white microcalli induced from control and media supplemented $100 \mathrm{mg} / \mathrm{L}$ aCaLS or $200 \mathrm{mg} / \mathrm{L}$ aNaLS were eventually regenerated into shoot. No sign of shoot regeneration was observed from the microcalli produced in other treatments. The highest microcallus production was obtained at 200 $\mathrm{mg} / \mathrm{L}$ aNaLS and the lowest at $100 \mathrm{mg} / \mathrm{L}$ aNaLS (Figure 2(E) \& 2(F)). Microcalli were friable and embryogenic with potential to differentiate into shoots (Figure 2(A) \& 2(B)).

In addition, total chlorophyll content analysis was greatly reduced in albino shoots induced from $100 \mathrm{mg} / \mathrm{L}$ aCaLS treatment (Figure 2(G)). In accordance to low total chlorophyll content, transcription level of the two chlorophyll-associated genes namely, chlorophyll $a / b$ binding protein $1(O s C A B 1 R)$ and young seedling albino (OsYSA), were also significantly down regulated in the albino shoots (Figure 2(H)). The OsYSA gene was not expressed, while $O s C A B 1 R$ gene expression was severely reduced by 0.76 -fold as compared to wild type.

\section{DISCUSSION}

Our study showed that aCaLS at concentration of 100 $\mathrm{mg} / \mathrm{L}$ significantly increased the callus proliferation rate of MR2 19 rice. Similarly, addition of CaLS was also reported to enhance callus growth of poplar (Kevers et al. 1999), growth of Phalaenopsis and as well as rooting of Sequoiadendron (Docquier et al. 2007). According to Docquier et al. (2007), the effects of LS could be indirect or 'delayed' and they hypothesized that CaLS may regulate either hormonal changes, mineral balancing or regulates the numbers of auxin receptor and their affinity to free auxin. In general, micronutrient ions such as $\mathrm{Fe}, \mathrm{Zn}$ and $\mathrm{Mn}$ are metal ions that could easily precipitate when there are changes in $\mathrm{pH}$ and chemical compositions. These solid complexes are not readily available to plant and thus, reduce the nutrient acquisition efficiency in plant. Therefore, LS could also act as a weak synthetic chelator that provides protection from 

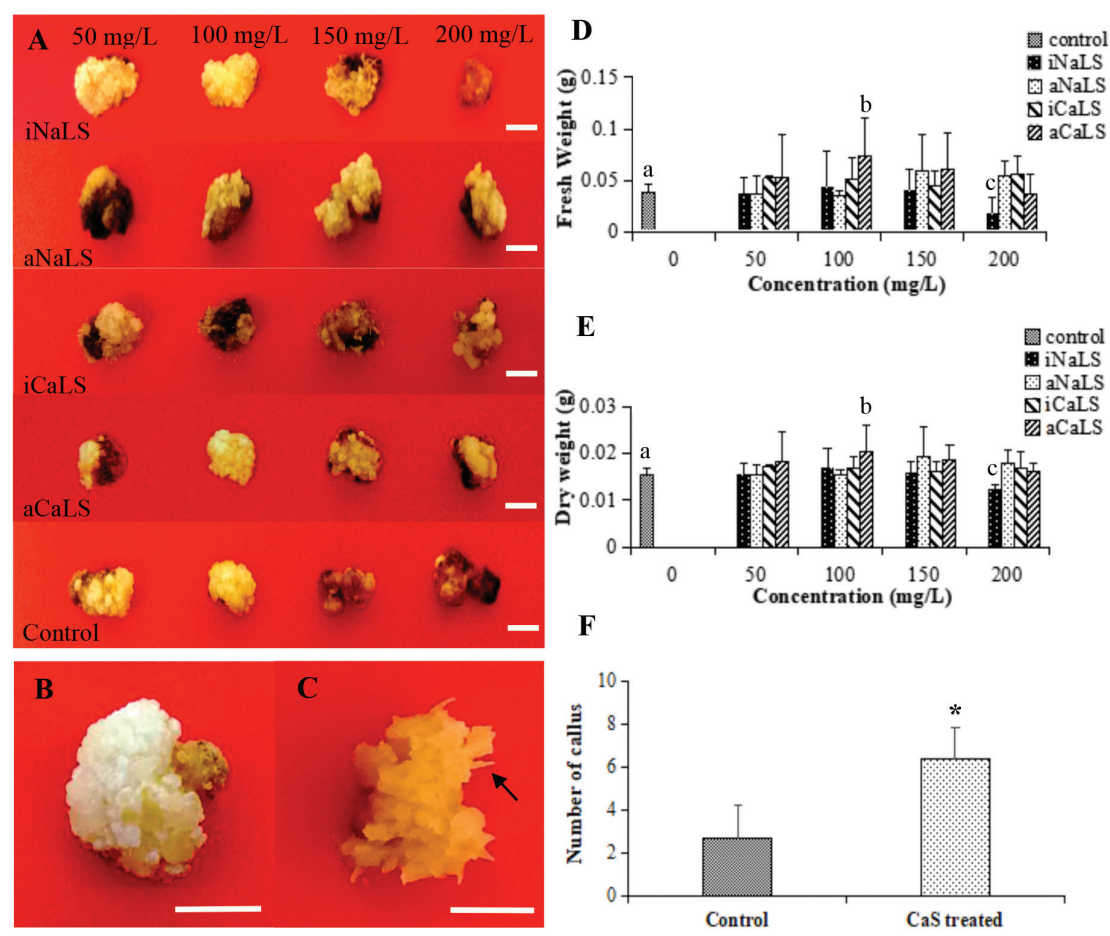

FIGURE 1. Callus proliferation treated with different types and concentrations of LS. (A) Morphology of callus, (B) Control callus, (C) $100 \mathrm{mg} / \mathrm{L}$ aCaLS-treated callus with adventitious root, (D \& E) Mean of FW and DW of three weeks old calli and (F) Number of callus observed with adventitious root formation in control and $100 \mathrm{mg} / \mathrm{L}$ aCaLS treatment. Data shows mean of three biological replicates. Different alphabets represent the significantly difference between treatments at $5 \%$ level according to Duncan's Test. Asterisk indicates statistical significance at $p<0.05$. Arrow shows adventitious root. Scale bars represent $0.5 \mathrm{~cm}$. Error bars represent standard deviation

insoluble complex formation and relatively fast release of the soluble micronutrient ions to cells for plant growth (Carrasco et al. 2012; Cieschi et al. 2016).

LS chelated calcium ions $\left(\mathrm{Ca}^{2+}\right)$ could prevent nutrient loss through precipitation due to $\mathrm{pH}$ changes or complex formation. Hence, availability of $\mathrm{Ca}^{2+}$ ions to plant in the medium increased. In general, $\mathrm{Ca}^{2+}$ is an essential micronutrient which plays a fundamental role as secondary signaling molecule in plant in response to environment stimuli (Tuteja \& Mahajan 2007). The increased level of $\mathrm{Ca}^{2+}$ in plant cell triggered the calcium-binding protein (calmodulin) and consequently activated the downstream calcium-dependent protein kinases. These protein kinases then regulate the functions of various genes involved in cell division and elongation, cytoplasmic streaming and plant defense (DalCorso et al. 2010; Park et al. 2008; Yang \& Poovaiah 2008). Hence, elevation of $\mathrm{Ca}^{2+}$ availability could be one of the major factors contributing to improve cell proliferation rate as seen in this study.

In shoot induction study, LS did not enhance the shoot induction efficiency as compared to control but a mixture of wild type and albino shoot populations were induced in aCaLS at $100 \mathrm{mg} / \mathrm{L}$. This phenomenon could be caused by disrupted interaction between auxin and cytokinin. Auxin and cytokinin are the main plant hormones that regulate root and shoot development. In general, high ratio of auxin to cytokinin induces root formation while high ratio of cytokinin to auxin induces shoot regeneration (Schaller et al. 2015; Skoog \& Miller 1957). Hence, we postulate that LS could be either elevating the endogenous auxin level that demotes shoot induction or depressing certain cytokinin transport proteins that affect the distribution of cytokinin throughout the cells.

To further understand the possible role of LS during shoot induction, gene expression analysis of chlorophyllassociated genes was performed. In plant, chlorophyll synthesis is controlled at multiple levels in both the nucleocytoplasmic and plastid compartments. The nuclearencoded $O S C A B 1 R$ gene encodes a light-harvesting chlorophyll a/b-binding protein of PSII, which are normally complexes with chlorophyll and xanthophylls and serve as the antenna complex to receive and transfer captured energy for the reaction centers of photosystem (Jansson 1999, 1994). Meanwhile, plastid-encoded OsYSA regulates the expression of genes related to chlorophyll biosynthesis, chloroplast development and photosynthesis in young seedling (Su et al. 2012). Our study demonstrated that the expression of both $O S C A B I R$ and $O S Y S A$ genes was markedly reduced upon addition of $100 \mathrm{mg} / \mathrm{L}$ aCaLS during shoot induction. Furthermore, our results also imply that the occurrence of albino shoot induction is ion and concentration dependent. Hence, specific ionchelated LS at optimum concentration may negatively regulate the transcript level of chlorophyll-associated genes, leading to chlorophyll synthesis disruption from both nucleocytoplamic and plastid levels. 

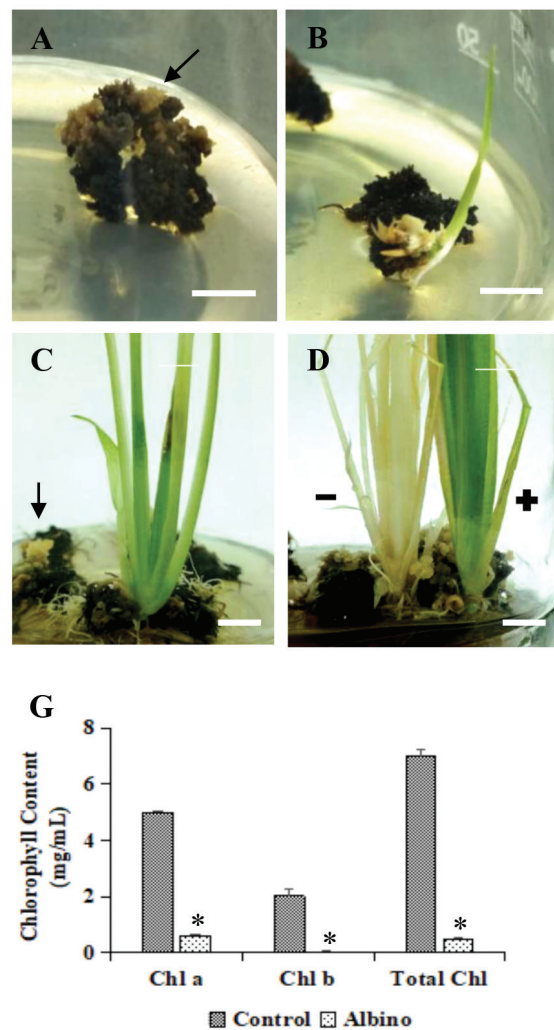

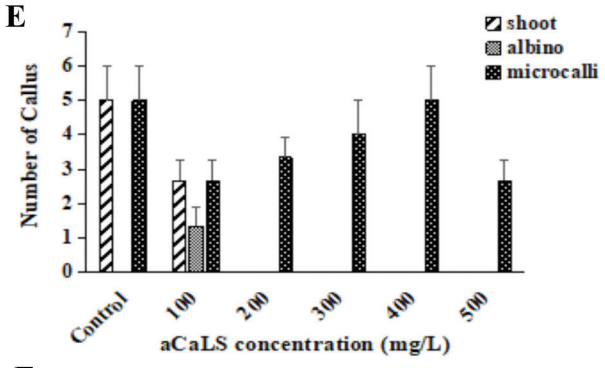

F

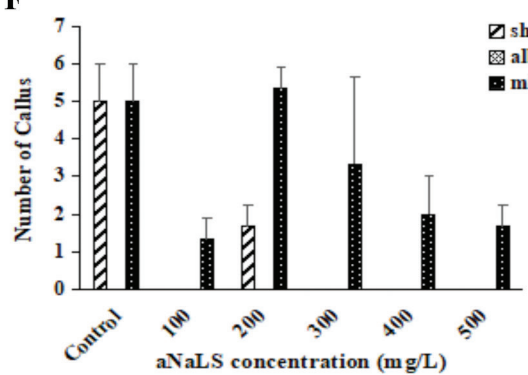

H

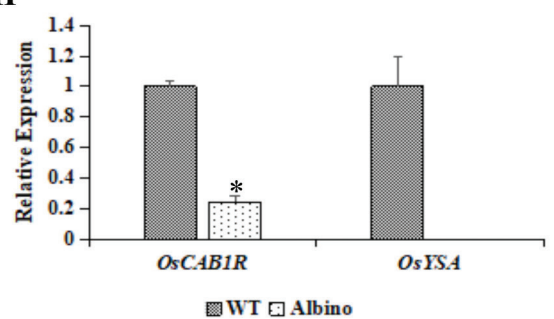

FIGURE 2. Shoot induction study treated with different types and concentrations of LS. (A \& B) Stages in MR219 shoot induction from callus, (C) Wild type shoot induced in control, (D) Albino (-) and wild type-like (+) shoots induced in $100 \mathrm{mg} / \mathrm{L}$ aCaLS, (E) The number of shoots, albino and microcalli observed in different concentrations of aCaLS treatments, (F) The number of shoots, albino and microcalli observed in different concentrations of aNaLS treatments, (G) The total chlorophyll, chlorophyll $\mathrm{a}$ and $\mathrm{b}$ content in control and albino shoots and $(\mathrm{H})$ Normalized relative expression of OSCAB1R and OsYSA in wild type (WT) and albino shoots. Data shows mean of three biological replicates. Asterisk indicates statistical significance at $p<0.05$. Arrows show microcalli. Scale bars represent $1 \mathrm{~cm}$. Error bars represent standard deviation

To date, the molecular mechanisms underlying the growth enhancing responses induced by LS is remained largely unknown. In the past, LS was postulated to play a role in regulation of endogenous auxin concentration (Gaspar et al. 1996; Hausman et al. 1995), auxin protector from enzymatic degradation, increase auxin-tissue sensitivity (Telysheva et al. 1997, 1992) and as well as to facilitate the transfer of macro and micronutrients into the plant cell compartments (Carrasco et al. 2012; Cieschi et al. 2016; Yamashita 1996). Nevertheless, concerted and detailed experiments need to be carried out to further confirm these growth enhancing effects of LS during plant growth.

\section{CONCLUSION}

Taken together, LS improves callus proliferation rate and modulates different physiological responses during plant growth of recalcitrant indica rice. Results gathered from this study could be used to enhance in vitro culture of recalcitrant indica rice, particularly in callus proliferation rate that will shorten the duration of cultivation.

\section{ACKNOWLEDGEMENTS}

The first author acknowledges the UPM Graduate Research Fellowship for supporting this research. The authors acknowledge the Ministry of Higher Education (MOHE), Malaysia (FRGS/1/2014/SG05/MOSTI/1) and UPM Putra Grant (GP-IPS/2016/9506100) for funding the research.

\section{REFERENCES}

Abiri, R., Maziah, M., Shaharuddin, N.A., Yusof, Z.N.B., Atabaki, N., Hanafi, M.M., Sahebi, M., Azizi, P., Kalhori, N. \& Valdiani, A. 2017. Enhancing somatic embryogenesis of Malaysian rice cultivar MR219 using adjuvant materials in a high-efficiency protocol. International Journal of Environmental Science and Technology 14(5): 1091-1108.

Almas, A.R., Afanou, A.K. \& Krogstad, T. 2014. Impact of lignosulfonate on solution chemistry and phospholipid fatty acid composition in soils. Pedosphere 24(3): 308-321.

Arnon, D.I. 1949. Copper enzymes in isolated chloroplasts, polyphenoxidase in Beta vulgaris. Plant Physiology 24(1): $1-15$.

Andrew Kok, D.X., Low, L.Y., Zetty, N.B.Y., Rogayah, S., Wee, C.Y. \& Lai, K.S. 2018. Iron biofortification of rice: Progress 
and prospects. Intech Open Croatia ISBN978-953-51-330-8 (In press).

Carrasco, J., Kovács, K., Czech, V., Fodor, F., Lucena, J.J., Vértes, A. \& Hernández-Apaolaza, L. 2012. Influence of pH, iron source, and $\mathrm{Fe} /$ ligand ratio on iron speciation in lignosulfonate complexes studied using Mössbauer spectroscopy. Implications on their fertilizer properties. Journal of Agricultural and Food Chemistry 60(13): 3331-3340.

Cieschi, M.T., Benedicto, A., Hernández-Apaolaza, L. \& Lucena, J.J. 2016. EDTA shuttle effect vs. lignosulfonate direct effect providing Zn to Navy Bean plants (Phaseolus vulgaris L. 'Negro Polo') in a calcareous soil. Frontiers in Plant Science 7: 1767.

DalCorso, G., Farinati, S. \& Furini, A. 2010. Regulatory networks of cadmium stress in plants. Plant Signaling and Behavior 5(6): 663-667.

Docquier, S., Kevers, C., Lambe, P., Gaspar, T. \& Dommes, J. 2007. Beneficial use of lignosulfonates in in vitro plant cultures: Stimulation of growth, of multiplication and of rooting. Plant Cell, Tissue and Organ Culture 90(3): 285-291.

Ertani, A., Francioso, O., Tugnoli, V., Righi, V. \& Nardi, S. 2011. Effect of commercial lignosulfonate-humate on Zea mays L. metabolism. Journal of Agricultural and Food Chemistry 59(22): 11940-11948.

Food and Agriculture Organization (FAO). 2017. GIEWS Global information and early warning system. The United Nation. http://www.fao.org/giews/countrybrief/country. jsp?code=MYS. Accessed by 10 November 2017.

Food and Fertilizer Technology Center (FFTC). 2002. MR219, A New High-Yielding Rice Variety with Yields of More than $10 \mathrm{MT} / \mathrm{Ha}$. For the Asian and Pacific Region. http://www. fftc.agnet.org/library.php?func=view\&id $=20110725142748$ \&type_id=8. Accessed on 11 December 2017.

Gamborg, O.L., Miller, R. \& Ojima, K. 1968. Nutrient requirements of suspension cultures of soybean root cells. Experimental Cell Research 50(1): 151-158.

Gaspar, T., Kevers, C., Penel, C., Greppin, H., Reid, D.M. \& Thorpe, T.A. 1996. Plant hormones and plant growth regulators in plant tissue culture. In Vitro Cellular and Developmental Biology Plant 32(4): 272-289.

Hausman, J.F., Kevers, C. \& Gaspar, T. 1995. Auxin-polyamine interaction in the control of the rooting inductive phase of poplar shoots in vitro. Plant Science 110(1): 63-71.

Htwe, N.N., Maziah, M., Ling, H.C., Zaman, F.Q. \& Zain, A.M. 2011. Responses of some selected Malaysian rice genotypes to callus induction under in vitro salt stress. African Journal of Biotechnology 10(3): 350-362.

Jansson, S. 1999. A guide to the $L h c$ genes and their relatives in Arabidopsis. Trends in Plant Sciences 4(6): 236-240.

Jansson, S. 1994. The light-harvesting chlorophyll a/b-binding proteins. Biochimica et Biophysica Acta 1184(1): 1-19.

Kevers, C., Soteras, G., Baccou, J.C. \& Gaspar, T. 1999. Lignosulfonates: Novel promoting additives for plant tissue cultures. In Vitro Cellular and Developmental BiologyPlant 35(5): 413-416.

Lai, K.S. \& Takehisa, M. 2013. Isolation and characterization of Arabidopsis thaliana self-incompatibility mutant induced by heavy-ion beam irradiation. Acta Biologica Cracoviensia Series Botanica 55(2): 146-152.

Lai, K.S., Yusoff, K. \& Mahmood, M. 2012. Heterologous expression of haemagglutinin-neuraminidase protein from Newcastle disease virus strain AF2240 in Centella asiatica. Acta Biologica Cracoviensia Series Botanica 54(1): 142-147.
Lai, K.S.,Puad, A., Yusoff, K. \& Mahmood, M. 2011.An efficient protocol for particle bombardment-mediated transformation of Centella asiatica. Acta Physiologiae Plantarum 33: 2547-2552.

Lim, Y.Y. \& Lai, K.S. 2017. Generation of transgenic rice expressing cyclotide precursor Oldenlandia affinis kalata B1 protein. Journal of Animal and Plant Sciences 27(2): 667-671.

Livak, K.J. \& Schmittgen, T.D. 2001. Analysis of relative gene expression data using real-time quantitative PCR and the 2- $\Delta \Delta C T$ method. Methods 25(4): 402-408.

Martinez-Trujillo, M., Cabrera-Ponce, J.L. \& Herrera-Estrella, L. 2003. Improvement of rice transformation using bombardment of scutellum-derived calli. Plant Molecular Biology Reporter 21(4): 429-437.

Mishra, R. \& Rao, G.J.N. 2016. In vitro androgenesis in rice: Advantages, constraints and future prospects. Rice Science 23(2): 57-68.

Murashige, T. \& Skoog, F. 1962. A revised medium for rapid growth and bio assays with tobacco tissue cultures. Physiologia Plantarum 15(3): 473-497.

Park, H.Y., Kim, S.A., Korlach, J., Rhoades, E., Kwok, L.W., Zipfel, W.R., Waxham, M.N., Webb, W.W. \& Pollack, L. 2008. Conformational changes of calmodulin upon $\mathrm{Ca}^{2+}$ binding studied with a microfluidic mixer. Proceedings of the National Academy of Sciences of the United States of America 105(2): 542-547.

Raghavendra, G., Kumaraswamy, G.K., Ramya, B., Sandesh, H.S., Yogendra, K.N., Deepak, N. \& Gowda, P.H.R. 2010. Direct multiple shoot regeneration of indica rice (Oryza sativa) Var. 'Rasi'. Asian and Australasian Journal of Plant Science and Biotechnology 4(1): 71-73.

Rodríguez-Lucena, P., Tomasi, N., Pinton, R., HernándezApaolaza, L., Lucena, J.J. \& Cesco, S. 2009. Evaluation of 59Fe-lignosulfonates complexes as Fe-sources for plants. Plant and Soil 325(1-2): 53.

Sah, S.K., Kaur, A., Kaur, G. \& Cheema, G.S. 2014. Genetic transformation of rice: Problems, progress and prospects. Rice Research 3(1): 132-142.

Sahoo, K.K., Tripathi, A.K., Pareek, A., Sopory, S.K. \& SinglaPareek, S.L. 2011. An improved protocol for efficient transformation and regeneration of diverse indica rice cultivars. Plant Methods 7(1): 49.

Schaller, G.E., Bishopp, A. \& Kieber, J.J. 2015. The yin-yang of hormones: Cytokinin and auxin interactions in plant development. The Plant Cell 27(1): 44-63.

Skoog,F. \& Miller, C.O. 1957. Chemical regulation of growth and organ formation in plant tissues cultured in vitro. Symposia of the Society for Experimental Biology 11: 118-130.

Su, N., Hu, M.L., Wu, D.X., Wu, F.Q., Fei, G.L., Lan, Y., Chen, X.L., Shu, X.L., Zhang, X., Guo, X.P. \& Cheng, Z.J. 2012. Disruption of a rice pentatricopeptide repeat protein causes a seedling-specific albino phenotype and its utilization to enhance seed purity in hybrid rice production. Plant Physiology 159(1): 227-238.

Telysheva, G., Lebedeva, G., Dizhbite, T., Zaimenko, N., Grivinya, D. \& Virzina, O. 1997. Novel ligno-silicon products promoting root system development. In Biology of Root Formation and Development. Basic Life Sciences 65, edited by Altman, A. \& Waisel, Y. Boston: Springer. pp. 92-93.

Telysheva, G., Lebedeva, G., Zaimenko, N. \& Viesturs, U. 1992. New lignosilicon fertilizers and their action on soil biota. International Symposium, Soil Decontamination using Biological Processes. Karlsruhe: Deutschland. pp. 525-530. 
Tuteja, N. \& Mahajan, S. 2007. Calcium signaling network in plants: An overview. Plant Signaling \& Behavior 2(2): 79-85.

van der Krieken, W., Kok, C. \& Stevens, L. 2004. Compositions Comprising Lignosulfonates for Crop Protection and Crop Improvement. U.S. Patent Application 10/543: 702.

Visarada, K.B.R.S. \& Sarma, N.P. 2004. Transformation of indica rice through particle-bombardment: Factors influencing transient expression and selection. Biologia Plantarum 48(1): 25-31.

Yamashita, T.T. \& Thomas, T. 1996. Method and Composition for Promoting and Controlling Growth of Plants. U.S. Patent $5,549,729$.

Yang, D., Qiu, X., Zhou, M. \& Lou, H. 2007. Properties of sodium lignosulfonate as dispersant of coal water slurry. Energy Conversion and Management 48(9): 2433-2438.

Yang, T. \& Poovaiah, B.W. 2008. Calcium/calmodulin-mediated signal network in plants. Trends in Plant Science 8(10): 505-512.

Yap, W.S. \& Lai, K.S. 2017. Biochemical properties of twelve Malaysia rice cultivars in relation to yield potential. Asian Journal of Agricultural Research 11(4): 137-143.

Zuraida,A.R.,Zulkifli,A.S., Habibuddin,H. \& Naziah, B. 2012. Regeneration of Malaysian rice variety MR219 via somatic embryogenesis. Journal of Tropical Agriculture and Food Science 39(2): 167-177.

Lee-Yoon Low, Janna Ong Abdullah \& Kok-Song Lai* Department of Cell and Molecular Biology

Faculty of Biotechnology and Biomolecular Sciences

Universiti Putra Malaysia

43400 UPM Serdang, Selangor Darul Ehsan

Malaysia
Chien-Yeong Wee \& Rogayah Sekeli

Biotechnology and Nanotechnology Research Centre

MARDI Headquarters

Persiaran MARDI-UPM

43400 Serdang, Selangor Darul Ehsan

Malaysia

Chun-Keat Tan

Agro-Biotechnology Institute Malaysia (ABI)

National Institutes of Biotechnology Malaysia (NIBM)

c/o MARDI Headquarters

43400 Serdang, Selangor Darul Ehsan

Malaysia

Jiun-Yan Loh

Functional Food Research Group

Faculty of Applied Sciences, UCSI University

No. 1, Jalan Menara Gading, UCSI Height

56000 Cheras, Kuala Lumpur, Federal Territory

Malaysia

*Corresponding author; email: laikoksong@upm.edu.my

Received: 2 February 2018

Accepted: 24 August 2018 